ПЕДАГОГІЧНИЙ СТОРІТЕЛІНГ У ПІДГОТОВЦІ

\title{
PEDAGOGICAL STORYTELLING IN THE TRAINING OF THE FUTURE HEALTHCARE PROFESSIONALS
}

у статmі розглянуто теоретико-методичні аспекти педагогічного сторітелінгу, його сутність, види та переваги перед іншими методами підготовки майбутніх срахівців у закладах вищої освіти; зроблено аналіз наукових праць із досліджуваної проблеми; виокремлено основні ффункції сторітелінгу як методу навчання на підставі аналізу наукових праць і власних спостережень і досвіду.

Метою статmі є теоретичне дослідження педагогічного сторітелінгу як методу навчання, визначення фрункцій і структури; обірунтування доцільності застосування його в профресійній підготовиі і становленні майбутніх фахівцівохорони здоров'я урармачевтичних і медичних закладах вищої освіти. Представлено орієнтовну структуру та сформульовано основні вимоги до педагогічного сторітелінгу й викладача, що виступає в ролі сторітелера; сорормульовано висновки про доцільність педагогічного сторіте лінгу та зазначено подальші перспективи наукових досліджень у підготовці майбутніх фрахівиів охорони здоров'я.

Виокремлено основні функції сторітелінгу як методу підготовки майбутніх срахівців охорони здоров'я та сфрормульовано основні вимоги й рекомендовану структуру, схарактеризовано основні етапи.

Окреслено вимоги до викладача-сторіте лера, який повинен бути спікером, володіти мистецтвом розказування історій, орієнтуватися в особливостях сторітелінгу, мати високу енергетику, уміти імпровізувати, тримати аудиторію (вербальний $і$ невербальний контакт), ураховуючи вікові особливості здобувачів освіти, психологічну amмосфреру.

На основі узагальнення різних підходів науковців і виходячи з власного педагогічного досвіду, ми сорормулювали методичні поради щодо застосування сторітелінгу в підготовці майбутніх фрахівців охорони здоров'я в закладах вищої освіти.

Результати дослідження свідчать, що педагогічний сторітелінг у профресійній підготовці майбутніх фрахівиів охорони здоров'я сприяє посиленню мотивації навчання та самомотивації, підвищенню якості рівня навчальних досягнень, профессійному становленню, розвитку професійно важливих та особистісних якостей як здобувачів освіти, так і викладачів.

Ключові слова: педагогічний сторітелінг, фрахівці охорони здоров'я, професійне становлення, розповідь, історія, функції сторітелінгу, сторітелер.
In this article we have investigated the theoretical and methodological aspects of pedagogical storytelling, its essence, types and advantages over other methods of the future professionals training in higher educational institutions; the analysis of scientific works on the researching problem has been made; we have allocated the main functions of storytelling as a method of teaching on the basis of the analysis of scientific works and our own observations and experience. The aim of the article is a theoretical study of pedagogical storytelling as a method of teaching, defining functions and structure; substantiation and expediency of its application in professiona training and formation of the future healthcare specialists in pharmaceutical and medical institutions of higher education.

The approximate structure has been presented and the basic requirements to the pedagogical storytelling and to the teacher acting as a storyteller have been formulated; conclusions have been formulated on the expediency of pedagogical storytelling and further prospects of scientific research have been indicated in the training of the future health professionals.

The main functions of storytelling as a method of future health professionals training have been highlighted and the basic requirements and recommended structure have been formulated, the main stages have also been characterized.

We have identified the requirements for a storyteller teacher, who must be a speaker, obtain the art of storytelling, get acquainted with the features of storytelling, possess a strong personality, be able to improvise, be able to keep the audience active (verbal and nonverbal contact), taking into account the age characteristics of applicants for higher education, psychological atmosphere etc.

Based on the generalization of different approaches of scientists and based on our own pedagogical experience, we have formulated the methodological advice on the use of storytelling in the training of the future health professionals in the higher education.

The results of the research show that pedagogical storytelling in the training of the future health professionals facilitates to strengthen the motivation of learning and selfmotivation, improve the academic achievement quality, professional development, development of professionally important and personal qualities of both applicants for higher education and teachers.

Key words: pedagogical storytelling, healthcare professionals, professional development, storytelling, storytelling functions, storyteller. Національного фрармацевтичного університету

Постановка проблеми в загальному вигляді. Посилення вимог до просресійної підготовки фрахівців охорони здоров'я в медичних і фармацевтичних закладах вищої освіти (далі - ЗВО) зумовлює пошук і реалізацію сучасних освітніх інновацій, форм, методів і засобів навчання.
Незважаючи на численні дослідження методів і педагогічних технологій у підготовці майбутніх срахівців, вектором наукового пошуку автора статті $€$ дослідження педагогічного сторітелінгу як методу професійної підготовки, донесення навчальної інформації до здобувачів освіти шляхом розповіді 
історій як 3 метою фрормування фрахових компетентностей, засобу посилення мотивації навчання, так і для самоосвіти й саморозвитку здобувачів.

Констатуємо, що у фрармацевтичній і медичній освіті поряд 3 іншими словесні методи використовується досить давно, але здебільшого поширеними $€$ такі як розповідь, бесіда, пояснення, диспут, дискусія, оповідь, наратив, обговорення, полеміка, круглий стіл тощо.

Нашу увагу привертає сучасний педагогічний сторітелінг, що може бути використаний в освітньому процесі з метою навчання та профресійного становлення майбутніх лікарів, провізорів, фрармацевтів та інших фрахівців охорони здоров'я.

Аналіз останніх досліджень і публікацій. Методи навчання у фрармацевтичній і медичній освіті $є$ предметом досліджень багатьох науковців, серед яких - О. Лисенко, Т. Муратова, Т. Пасько, Р. Слухенська, А. Єрохова й ін.

Зокрема, дослідженню елементів сторітелінгу як навчального методу в поглядах педагогів, громадських діячів минулого присвячена наукова праця С. Микитюк. Автор відзначає, що сторітелінг виник не спонтанно, а має ґрунтовні, міцні теоретичні засади, що сорормовані в процесі освітньої діяльності та є надбанням педагогічного досвіду відомих педагогів і громадських діячів, серед яких - А. Макаренко, В. Сухомлинський та ін. [7].

Привертає увагу дослідження Ю. МаковецькоїГудзь, котра наголошує, що метод сторітелінгу сприяє орормуванню в студентів орієнтовної основи поведінки в мовних ситуаціях; ознайомленню студентів із варіантами мовних дій, умінь їх комбінувати й знаходити нові рішення. Виробляється впевненість у володінні прийомами, заснованими на особистому досвіді; створюється досвід вираження своєї особистісної позиції в спілкуванні, адекватної самооцінки «продуктів спілкування», уміння презентувати себе [6].

У процесі наукового пошуку встановлено, що методика сторітелінгу розроблена й успішно випробувана на особистому досвіді Девідом Армстронгом, головою міжнародної компанії Armstrong International [1].

Зауважимо, що в публікації Симмонс Аннет «Сторителлинг. Как использовать силу историй» висвітлено особливості сторітелінгу, наведена типологія, структура, зміст історій і підходи щодо їх створення, вплив розповіді на емоції та мотивацію слухача, який може бути використано в освітньому процесі майбутніх фрахівців охорони здоров'я [9].

Медичні історії, билини, курйози, розповіді й оповідання, що стали сюжетом багатьох наукових, мемуарних, бібліографрічних і художніх видань [3], виконують мотивувальну, спонукальну, повчальну фрункції в навчанні та профресійному становленні майбутніх фрахівців охорони здоров'я.
Аналіз наукових праць із досліджуваної проблеми дає підстави стверджувати, що останнім часом метод сторітелінгу (story - історія; telling розповідати) $€$ предметом наукових досліджень вітчизняних і зарубіжних учених.

Виділення не вирішених раніше частин загальної проблеми. Профресійна підготовка і становлення майбутніх лікарів, провізорів, фрармацевтів, медичних сестер та інших фрахівців галузі охорони здоров'я в закладах вищої освіти ґрунтуються на кращих традиціях вітчизняної та зарубіжної фармацевтичної та медичної освіти й науки, але вони потребують постійного вдосконалення, відповідності міжнародним стандартам і рекомендаціям.

Нашу увагу в дослідженні привертає сучасний педагогічний сторітелінг, що може бути використаний в освітньому процесі з метою навчання та профресійного становлення майбутніх лікарів, провізорів, фрармацевтів та інших фрахівців охорони здоров'я як один із сучасних методів навчання.

Мета статті полягає в теоретичному дослідженні педагогічного сторітелінгу як методу навчання, визначенні фрункцій і структури; обґрунтуванні й доцільності застосування його в професійній підготовці та становленні майбутніх фрахівців охорони здоров'я у фрармацевтичних і медичних закладах вищої освіти.

Виклад основного матеріалу. Нам імпонує дослідження методів навчання в процесі фрормування творчого потенціалу майбутніх лікарів 3 метою спонукання їх до активності, творчої самостійності, накопичення особистісного досвіду, серед яких - діалогічні фрорми й методи (дискусії, аналіз клінічних ситуацій, інтерактивні лекції); активні та евристичні методи (мозковий штурм, синектика тощо). Застосування методу бесіди, на думку Р. Слухенської, сприяє активізації розумової діяльності майбутніх лікарів, оскільки, ґрунтуючись на основі запитань-відповідей викладача і студентів, бесіда передбачає включення майбутніх лікарів у професійну діяльність, спрямовує їхню активність на застосування й відтворення здобутих професійних знань. З'ясовано, що результат бесіди безпосередньо залежить від діалогічної майстерності викладача, його культури спілкування [10].

Загальновідомо, що розповідь $є$ методом усного викладу навчальної інфрормації, яка використовується під час монологічного викладення навчальної інформації (фрактів, подій, явищ, висновків тощо) і сприяє розвитку критичного мислення здобувачів освіти, їхньої логіки, уяви, креативності тощо.

Зауважимо, що педагогічний сторітелінг у дослідженні розглядаємо як один із ефективних методів донесення інформації до аудиторії шляхом розповіді (переказування) історій з реальними або вигаданими персонажами. 
Проведений науковий пошук, ознайомлення 3 науковими працями 3 досліджуваної проблеми, досвід підготовки майбутніх фрахівців охорони здоров'я дали змогу виокремити основні фуннкії сторітелінгу, серед яких:

- освітня (формування профресійних компетентностей, знань, умінь і навичок; розвиток профресійно важливих якостей);

- мотиваційна (навіювання, надихання, зацікавлення);

- переконувальна (залучення на свою позицію, зміна поглядів та установок, переконань);

- розвивальна (розвиток розумово-пізнавальних здібностей);

- об'єднувальна (з метою розвитку дружніх, колективних стосунків);

- комунікативна (ефективне спілкування);

- наставницька (співпраця більш досвідчених 3 менш досвідченими);

- виховна (приклади з власного досвіду, професійного й особистого життя, поради та рекомендації).

Зважаючи на вищевикладене, узагальнюючи напрацювання науковців і власний досвід, ми сорормулювали такі основні вимоги до сторітелінгу:

- наявність головної ідеї чи персонажу;

- історії повинні бути підготовленими, продуманими, реалістичними, цікавими, повчальними, вражаючими;

- повинна бути чітка логіка, структурованість і послідовність;

- викладач не повинен нав'язувати свою думку;

- основними в історії є люди та події;

- доцільно використовувати метафори, порівняння, аналогію;

- історія завжди відбувається 3 конкретним персонажем чи персонажами

- це може бути професійна або життєва історія (як успішна, так і ні);

- історія повинна бути корисною, мотивуючою, цікавою.

В аспекті досліджуваної проблеми вважаємо за необхідне наголосити, що орієнтовна структура сторітелінгу має такі етапи:

1. Вступ.

2. Контент (наповнення, зміст).

3. Кульмінація.

4. Завершальний етап (висновки, резюме, поради та рекомендації, зворотній зв'язок).

У вступній частині сторітелінгу оповідач привертає увагу аудиторії та налаштовує слухачів до сприйняття історії. На цьому етапі встановлюється психологічний контакт до вербального й невербального спілкування, створюються сприятливі умови для впливу на аудиторію, привертається увага, знімається напруження, забезпечується позитивна мотивація до навчання. Це вміння викладача «подати себе», зацікавити здобувачів освіти, заволодіти їхньою увагою, обрати певний стиль мовлення для конкретної аудиторії. Безумовно, розповідати історії - це завдання нелегке. Це мистецтво комунікацій, один із методів впливу на аудиторію, уміння створювати сприятливу атмосореру для навчання. Сторітелеру важливо усвідомлювати, з якою метою і для якої аудиторії він розповідає конкретну історію.

Контент сторітелінгу має бути цікавим, корисним, добре продуманим і підготовленим. Історія повинна містити інтригу й бути побудованою 3 дотриманням логіки та послідовності. Це можуть бути веселі й сумні історії, щасливі й нещасливі. У таких історіях сторітелер може навести приклади з допущенням помилок і невдач у професійній діяльності.

Кульмінація сторітелінгу є основним етапом розповіді, що має головний сюжет, поворотну подію, головну думку, інтригу, протиріччя чи ідею, розв'язку. На основі узагальнення різних підходів з'ясовано, що ця частина сторітелінгу повинна мати цікаві фракти з профресійного життя, як 3 власного досвіду, так і з життя колективу, закладу чи установи. Це може бути історія про себе, колегу чи колег; вигадана історія; про історичний персонаж тощо. Педагогічний сторітелінг можна доповнити презентацією, відео чи аудіо, фото тощо, зачитати уривки з книг, прочитати вірші тощо.

На завершальному етапі необхідно підвести підсумки, зробити узагальнення, сорормулювати висновки та короткі рекомендації, дати відповіді на запитання слухачів, подякувати за увагу.

Автор статті акцентує увагу на необхідності широкого використання педагогічного сторітелінгу в підготовці майбутніх фрахівців охорони здоров'я лікарів провізорів, фрармацевтів, медичних сестер та ін.), у професійному становленні, оскільки, на нашу думку, цей метод є переконливим, доступним, мотиваційним, спонукальним, стимулювальним.

Важливим $є$ той фракт, що фрахівці медичних і фрармацевтичних професій у діяльності мають справу з однією з головних цінностей - здоров'ям людини. Здоров'я людини є цінним скарбом, комплексом духовних, психічних і фрізичних якостей, показником стану організму, що забезпечує працездатність, щасливий стан і можливість займатися професійною діяльністю й особистим життям.

Реалізація педагогічного сторітелінгу в підготовці майбутніх фрахівців охорони здоров'я у фрармацевтичних і медичних ЗВО посилює вимоги до викладача та його компетентностей і якостей. Викладач виступає в ролі сторітелера, а це передбачає, що викладач повинен бути спікером, володіти мистецтвом розказування історій, орієнтуватися в особливостях сторітелінгу, мати високу енергетику, уміти імпровізувати, уміти тримати аудиторію (вербальний і невербальний контакт), ураховуючи вікові особливості здобувачів освіти, психологічну атмосореру тощо. Це зумовлює не 
тільки володіння профресійними знаннями й уміннями, методиками викладання навчальних дисциплін, а бути гнучким, упевненим, уміти швидко адаптуватися до змін, бути готовим до упровадження освітніх інновацій і реалізації нових наукових ідей, підходів, кращого вітчизняного та зарубіжного досвіду в профресійну підготовку майбутніх фрахівців охорони здоров'я.

Уважаємо, що ефективність сторітелінгу залежить від особистості викладача, його профресійного досвіду та педагогічної майстерності, уміння зацікавити й мотивувати здобувачів освіти до навчання та самоосвіти. Для цього викладачеві необхідно обрати ефективний стиль і використовувати різні методики й педагогічні техніки, бути природнім та емоційним, відвертим та іронічним, енергійним і харизматичним.

Наведемо приклади педагогічного сторітелінгу, що можуть бути використані в підготовці майбутніх фахівців охорони здоров'я у ЗВО. Це може бути історія, яку викладач розповідає: про заклад вищої освіти або заклад чи установу охорони здоров'я; про кафедру; про професію фрахівців медицини чи фрармації; роботу в аптеці чи в лікувальному закладі; під час презентації кафредри, наукових шкіл, освітньо-професійних програм тощо; під час профорієнтаційних заходів.

Зауважимо, що саме історії визивають різні емоції та почуття: радість, гнів, переживання, інтерес, захоплення, здивування, емпатію, розчарування, натхнення, обурення, співчуття тощо. Важливим $є$ той фракт, що історії можуть бути як із профресійного, так і повсякденного життя з метою розкриття потенційних можливостей особистості, її інтересів і цінностей, із залученням цікавих фрактів.

Проведені дослідження дали змогу навести приклади педагогічного сторітелінгу в підготовці майбутніх фрахівців охорони здоров'я: як я став лікарем чи провізором, викладачем медичного чи фрармацевтичного 3ВО; що мене приваблює в моїй професії; досвід роботи в аптеці чи лікувальному закладі; клінічні ситуації; курйози лікарської чи фрармацевтичної практики; історії про пацієнтів тощо.

На основі узагальнення різних підходів науковців і виходячи з власного педагогічного досвіду, ми сорормулювали такі методичні поради щодо застосування сторітелінгу в підготовці майбутніх фрахівців охорони здоров'я в закладах вищої освіти:

- продумайте, що Ви будете розповідати;

- умійте за мотивувати;

- розповідайте про те, що є цікавим;

- розділіть історію на частини;

- будьте впевнені й переконливі;

- діліться своїм досвідом і профресійним успіхами;

- тримайте інтригу;

- контролюйте свою мову, ритм, інтонацію і тембр мовлення;
- відчувайте аудиторію;

- будьте стислими;

- передавайте емоції й почуття;

- володійте акторською майстерністю.

- демонструйте Ваші сильні сторони, професійні й особисті досягнення.

Отже, проводячи власні дослідження та інтегруючи підходи вітчизняних і зарубіжних дослідників щодо сторітелінгу, можемо стверджувати, що цей метод $€$ перспективним і мотивуючим у професійній підготовці фрахівців охорони здоров'я як на до дипломному, так і післядипломному рівні освіти.

Висновки. Авторська позиція полягає в тому, що педагогічний сторітелінг у професійній підготовці майбутніх фрахівців охорони здоров'я сприяє посиленню мотивації навчання та самомотивації, підвищенню якості рівня навчальних досягнень, профресійному становленню, розвитку профресійно важливих та особистісних якостей як здобувачів освіти, так і викладачів.

Проведене дослідження не вичерпує всіх аспектів наукового дослідження із цієї проблеми, її подальшу перспективу буде спрямовано на пошук і реалізацію освітніх інновацій у підготовку фахівців охорони здоров'я.

\section{БІБЛІОГРАФІЧНИЙ СПИСОК:}

1. Аналіз методу навчання Story Telling. URL: http://bibliofond.ru/view.aspx?id=788263\#1.

2. Біланова Л.П. 3 досвіду використання сучасних освітніх технологій на заняттях медичної біології у медичному коледж. URL: http://elib.umsa.edu.ua/ jspui/bitstream/umsa.

3. Білоус В.І., Білоус В.В. Історія медицини і лікувального мистецтва. Чернівці, 2019. 284 с.

4. Хатченс Д. 9 техник сторителлинга. URL: http://www.management.com.ua/books/view-books. php?i анг.

5. Лисенко О. Інтерактивні методи навчання у післядипломній підготовці лікарів. Педагогічний процес: теорія і практика. 2016. Вип. 2. С. 50-53.

6. Маковецька-Гудзь Ю.А. Storytelling в педагогічній практиці розвиток комунікативного потенціалу. URL: http://kumlk.kpi.ua/sites/default/.

7. Микитюк С.О. Елементи сторітелінгу як навчального методу у поглядах педагогів, громадських діячів минулого. URL: http://www.chasopys.ps. npu.kiev.ua/archive.

8. Муратова Т.М., Добровольський В.В. Особливості використання бесіди, як форми активного навчання, під час виховного та навчального процесу на кафредрі неврології Одеського національного медичного університету. Медична освіта. 2015. № 1. С. 81-83.

9. Симмонс А. Сторителлинг. Как использовать силу историй. URL: https://2brilliant.ru/wp-content/ uploads/2015/04/A-Simmons-Storitelling.pdf.

10. Слухенська Р.В., Єрохова А.А., Пасько Т.В. Інтерактивні методи навчання у процесі професійної підготовки майбутніх лікарів. URL: file:///C:/Documents\%20 and\%20Settings.

11. Сторітеллінг як ефективний варіант неформального навчання. URL: http://ar25.org/article/ storitelling. 